\title{
MENINGKATKAN HASIL BELAJAR MATEMATIKA SISWA SD KELAS 4 MENGGUNAKAN MODEL PEMBELAJARAN DISCOVERY LEARNING BERBASIS KURIKULUM 2013
}

\author{
Rosemey Ratna Purnawati', Slameto' ${ }^{2}$ Elvira Hoesein Radia ${ }^{3}$ \\ ${ }^{1,2,3}$ Pendidikan Guru Sekolah Dasar, Universitas Kristen Satya Wacana, rosemeyosi@gmail.com
}

\begin{tabular}{|c|c|}
\hline INFO ARTIKEL & ABSTRAK \\
\hline Riwayat Artikel: & Abstrak: Penelitian ini bertujuan untuk meningkatkan hasil belajar matematika \\
\hline Diterima: $20-03-2018$ & $\begin{array}{l}\text { menggunakan model pembelajaran Discovery Learning berbasis Kurlkulum } 2013 \text { pada siswa } \\
\text { kelas } 4 \text { di salah satu SD Negeri kota Salatiga. Jenis penelitian ini adalah penelitian tindakan }\end{array}$ \\
\hline Disetujui: 04-04-2018 & $\begin{array}{l}\text { kelas dengan dua siklus. Siklus I dan II terdiri dari tiga kali pertemuan. Subjek penelitian } \\
\text { adalah siswa kelas } 4 \text {. Pada kondisi awal nilai rata-rata klasikal adalah } 62,25 \text { dengan jumlah }\end{array}$ \\
\hline Kata Kunci: & I rata-rata hasil belajar matematika meningkat menjadi 75,50 dan pada siklus II rata-rata \\
\hline Dicovery Learning & juga mengalami peningkatan. Pada siklus I presentase ketuntasan mencapai $75 \%$ dan pada \\
\hline Kurikulum 2013 & siklus II presentase ketuntasan mencapai $90 \%$, dengan demikian dapat disimpulkan bahwa \\
\hline Hasil Belajar & model pembelajaran Discovery Learning berbasis Kurikulum 2013 dapat meningkatkan hasil \\
\hline Matematika & belajar. \\
\hline
\end{tabular}

\begin{abstract}
This study aims to improve the learning outcomes of mathematics through Discovery Learning based on 2013 curriculum model in the fourth grade students on one of the Salatiga State Elementary Schools. This type of research is a Classroom Action Research with two cycles. Both cycles consist of three meetings. The subjects of the study were the fourth grade students. The initial condition showed that the score was 62,25 with the total number of students who passed were only 10 students and the number of students who hasn't passed were 10 students. At the first cycle of mathematics learning the outcomes increased to become 75,50. It means the percentage of completeness reached $75 \%$. At the second cycle the average of student's learning outcomes increased again to become 83,00. Showed that percentage of completeness reached $90 \%$, thus it can be concluded that the Discovery Learning based on 2013 curriculum model can improve student learning outcomes.
\end{abstract}

\section{A. LATAR BELAKANG}

Kurikulum 2013 bermaksud bagi manusia Indonesia agar memiliki kemampuan hidup sebagai pribadi dan warga negara yang berkeyakinan, produktif, kreatif, inovatif, dan afektif serta mampu berkontribusi pada kehidupan bermasyarakat, berbangsa, bernegara, dan peradaban dunia. Penarapan kurikulum 2013 harus mengandung kegiatan literasi, berpikir tingkat tinggi (Higher Order of Thinking Skill), 4C (Communication, Collaboration, Critical Thinking and Problem Solving, dan Creativity and Innovation) dan pendidikan karakter. Selain itu, pembelajaran harus pula menggunakan pendekatan saintifik (Permendikbud, 2016).

Dalam kurikulum 2013 di jenjang sekolah dasar terdapat mata pelajaran matematika. Matematika ialah kumpulan dari kebenaran dan aturan, ilmu matematika bukan sekedar hanya berhitung saja. Matematika merupakan suatu bahasa, kegiatan untuk pembangkitan masalah serta untuk memecahkan suatu masalah, kegiatan untuk menemukan serta untuk mempelajari pola dan hubungan (Riedesel, 1996). Dalam pembelajaran matematika, guru memberikan kesempatan kepada siswa untuk melakukan kegiatan penemuan dan penyelidikan pola-pola dan untuk menentukan hubungan. Guru harus memberikan kesempatan kepada siswa untuk berpikir berbeda menggunakan pola pikir mereka sendiri sehingga menghasilkan penemuan mereka sendiri (Ebbut, 1995). Oleh sebab itu, penggunaan model pembelajaran harus dilandaskan pada pertimbangan untuk menempatkan siswa sebagai subjek belajar yang tidak hanya pasif saat belajar di dalam kelas. Namun guru harus berupaya menciptakan pembelajaran yang menimbulkan masalah matematika yang harus dipecahkan oleh siswa menggunakan cara mereka sediri.

Berdasarkan observasi yang dilakukan, pembelajaran di kelas 4 di salah satu SD Negeri kota 
Salatiga, guru menjadi sumber belajar dengan memberikan banyak penjelasan materi pelajaran. Guru masih dominan menggunakan model pembelajaran yang hanya memberikan pengetahuan kepada siswa. Hal ini berarti siswa hanya menerima pengetahuan dari guru, padahal dalam Kurikulum 2013 guru harus mengembangkan pembelajaran yang merangsang siswa untuk mendapatkan pengetahuannya sendiri. Sehingga yang terjadi adalah belum terpenuhinya pembelajaran yang mengandung $4 \mathrm{C}$ (Communication, Collaboration, Critical Thinking and Problem Solving, dan Creativity and Innovation) dan $5 \mathrm{~m}$ (mengamati, menanya, mencoba, mengasosiasi, dan mengomunikasikan) yang harus ada pada proses siswa saat mendapatkan pengetahuan. Akibatnya, pemahaman siswa terhadap pelajaran matematika rendah dibuktikan dengan nilai siswa yang belum mencapai KKM sebanyak 10 (50\%) dari 20 siswa pada ulangan matematika. Oleh karena data tersebut perlu adanya inovasi pembelajaran matematika untuk meningkatkan hasil belajar siswa.

Salah satu bentuk inovasi pembelajaran pembelajaran matematika adalah dengan guru memberikan kesempatan kepada siswa untuk melakukan kegiatan penemuan dan penyelidikan polapola dan untuk menentukan hubungan. Inovasi pembelajaran yang akan dikembangkan adalah Discovery Learning berbasis Kurikulum 2013. Discovery Learning merupakan salah satu model pembelajaran yang memungkinkan siswa terlibat langsung dalam kegiatan belajar-mengajar, sehingga mampu menggunakan proses mentalnya untuk menemukan suatu konsep atau teori yang sedang dipelajari (Illahi, 2012: 33). Ide dasar dari pembelajaran Discovery Learning adalah bahwa siswa dapat merancang eksperimen mereka sendiri di ranah dan menyimpulkan aturan materi mereka, karena mereka sebenarnya membangun pengetahuan mereka. Kegiatan pembelajaran ini, diasumsikan siswa akan memahami materi pelajaran pada tingkat yang lebih tinggi daripada ketika informasi yang diperlukan hanya disajikan oleh guru atau lingkungan pembelajaran ekspositori (Van Joolingen, 1998: 386). Penelitian Pakpahan (2014: 88) menunjukkan bahwa dengan menggunakan model Discovery Learning dapat meningkatkan hasil belajar siswa. Terbukti dari analisis data siklus I diperoleh 13 (43,33\%) siswa telah mencapai KKM. Pada siklus II diperoleh 27 (90\%) siswa telah mencapai KKM. Hasil penelitian Astuti (2015: 21) juga menunjukan penggunaan model pembelajaran Discovery Learning meningkatkan hasil belajar matematika, dari siklus I sebesar 46,6\% menjadi 80,00\% diakhir siklus II.

Model pembelajaran Discovery Learning yang dikembangkan sendiri oleh penulis dengan melakukan bebarapa perubahan pembelajaran berbasis Kurikulum 2013 yaitu yang pertama, langkah-langkah model Discovery Learning mengandung $5 \mathrm{~m}$ (menanya, mengamati, menalar, mencoba, dan mengkomunikasikan). Kedua, pada tahap data collections atau pengumpulan data dalam langkahlangkah pembelajaran Discovery Learning, disediakan beberapa pertanyaan untuk menuntun siswa berpikir kritis (critical thinking). Ketiga, kegiatan evaluasi dilakukan dengan soal-soal yang memuat HOTS. Oleh karena itu, tujuan penelitian ini yaitu meningkatkan hasil belajar siswa kelas 4 di salah satu SD Negeri kota Salatiga pada mata pelajaran matematika melalui penerapan model pembelajaran Discovery Learning berbasis Kurikulum 2013. Secara teoritis penelitian ini berguna memperkaya hasil penelitian untuk menjadi rujukan bagi peneliti yang akan datang mengenai penelitian dengan menggunakan model pembelajaran Discovery Learning dalam kaitannya dengan menciptakan kondisi belajar bermuatan $4 \mathrm{C}$ (khususnya critical thinking) dalam pelajaran matematika.

Hasil belajar adalah suatu akibat dari proses belajar dengan menggunakan alat pengukuran yaitu berupa tes yang disusun secara terencana, baik tes tertulis, tes lisan maupun tes perbuatan (Sudjana, 2004: 14). Dari pengertian tersebut, proses pembelajaran berpengaruh pada hasil belajar yang diukur dengan tes. Jika, pembelajaran tidak bermakna maka hasil belajar menjadi rendah. Kondisi rendahnya aktivitas siswa juga berdampak pada rendahnya prestasi belajar (Hapsari, 2017: 6).

\section{B. METODE PENELITIAN}

Penelitian Tindakan Kelas (PTK) ini dilakukan pada mata pelajaran matematika di salah satu SD Negeri di Salatiga siswa kelas 4 semester II Tahun Pelajaran 2017/ 2018 dengan jumlah siswa 20 siswa. Penelitian ini bertujuan untuk mengetahui penigkatan hasil belajar matematika dapat diupayakan melalui model pembelajaran Discovery Learning berbasis Kurikulum 2013. Jenis penelitian ini adalah penelitian tindakan kelas yang dilakukan sebanyak 2 siklus, masing-masing terdiri dari 3 tahapan yaitu 1) perencanaan tindakan, 2) pelaksanaan tindakan dan observasi, 3) refleksi. Dalam penelitian ini, teknik pengumpulan data variabel terikat yaitu menggunakan tes. Teknik tes digunakan untuk mengukur kemampuan berpikir kritis siswa setelah menerapkan pembelajaran matematika menggunakan model pembelajaran Discovery Learning berbasis Kurikulum 2013. Tes tersebut digunakan untuk mengukur aspek kognitif dengan instrumen butir soal. Sedangkan teknik pengumpulan data variabel bebas yaitu menggunakan non tes yaitu observasi dengan instrumen lembar observasi aktivitas guru dan siswa. Teknik analisis data ada 2 yaitu analisis ketuntasan dan analisis komparatif. Analisis ketuntasan untuk mengetahui besarnya siklus yang tuntas atau tidak tuntas dari pra siklus, siklus 1 dan siklus 2. Sedangkan analisis komparatif untuk membandingkan hasil belajar pra siklus, siklus 1, siklus 2 sehingga dapat dikaitkan dengan kenaikan hasil belajar antar siklus. Indikator 
kinerja dalam penelitian ini menetapkan keberhasilan penelitian dilihat dari ketuntasan individual dan ketuntasan secara klasikal. Ketuntasan individual bagi siswa diukur dari ketercapaian nilai siswa terhadap Kriteria Ketuntasan Minimal (KKM). KKM yang digunakan di sekolah adalah 67 , dalam penelitian ini juga menerapkan KKM adalah 67 dengan ketuntasan belajar mencapai $80 \%$.

\section{HASIL DAN PEMBAHASAN}

\section{Pra Siklus (Kondisi Awal)}

Data pra siklus atau kondisi awal dalam penelitian ini didapat dari hasil nilai ulangan harian matematika semester genap pada mata pelajaran matematika siswa kelas 4. Hal ini bertujuan untuk mengetahui hasil belajar siswa pada mata pelajaran matematika dengan nilai KKM (Kriteria Ketuntasan Minimal) yaitu 67. Berikut ini nilai pra siklus dari daftar nilai siswa yang dijabarkan dan distribusi ketuntasan hasil belajar matematika pada tabel 1 sebagai berikut.

TABEL 1

KETUNTASAN HASIL BELAJAR MATEMATIKA SISWA KELAS 4 PRA SIKLUS

\begin{tabular}{|c|c|c|c|c|}
\hline \multirow[b]{2}{*}{ No } & \multirow[b]{2}{*}{ Nilai } & \multirow{2}{*}{$\begin{array}{c}\text { Ketuntasan } \\
\text { Belajar }\end{array}$} & \multicolumn{2}{|c|}{ Jumlah siswa } \\
\hline & & & Jumlah & $\begin{array}{l}\text { Presen- } \\
\text { tase (\%) }\end{array}$ \\
\hline 1. & 67 & Tuntas & 10 & 50 \\
\hline 2. & $<67$ & Belum tuntas & 10 & 50 \\
\hline \multicolumn{3}{|c|}{ Jumlah } & 20 & 100 \\
\hline \multicolumn{3}{|c|}{ Rata - rata } & 62,25 & \\
\hline \multicolumn{3}{|c|}{ Nilai Tertinggi } & 90 & \\
\hline \multicolumn{3}{|c|}{ Nilai Terendah } & 20 & \\
\hline
\end{tabular}

Dari tabel 1 di atas, ketuntasan belajar siswa pra siklus masih dikatakan rendah yaitu dengan prosentase $50 \%$. Perbandingan siswa yang mencapai KKM (67) adalah sebanyak 10 siswa. Sedangkan siswa yang belum mencapai KKM sebanyak 10 siswa. Terlihat pula kesenjangan nilai yang begitu juah antara nilai terendah dan nilai tertinggi. Diharapkan dengan menggunakan model pembelajaran Discovery Learning berbasis Kurikulum 2013, siswa yang belum tuntas dapat diperbaiki karena sejatinya model pembelajaran akan berpengaruh pada hasil belajar. Serupa dengan pernyataan bahwa penggunaan model pembelajaran akan memiliki peran penting pada hasil belajar siswa (Pratiwi, 2014: 3).

\section{Hasil Penelitian Siklus I}

a. Perencanaan

Hasil evaluasi yang diadakan pra siklus menjadi acuan untuk mengambil tindakan yang tepat untuk meningkatkan hasil belajar siswa pada pelajaran matematika. Penelitian pada siklus I terdiri dari 3 kali pertemuan. Dalam perencanaan siklus 1 guru: 1) menyusun rencana pembelajaran dengan menerapkan model pembelajaran
Discovery Learning berbasis Kurikulum 2013. 2) menyiapkan media pembalajaran berupa kertas persegi/ persegi panjang dan persegi satuan untuk memudahkan siswa dalam membangun pengetahuannya sendiri. 3) menyiapkan tugas kelompok. 4) menyiapkan tes akhir tiap siklus dengan materi luas dan keliling bangun persegi dan persegi panjang, bentuk tesnya adalah uraian (HOTS). 5) menyiapkan lembar observasi kegiatan belajar mengajar guru dan siswa dalam pembelajaran menggunakan model pembelajaran Discovery Learning berbasis Kurikulum 2013.

\section{b. Pelaksanaan Tindakan}

Langkah-langkah pelaksanaan pembelajaran pada siklus I yang diterapkan oleh peneliti dimulai dengan guru melakukan stimulations pada apersepsi untuk membangun rasa keingintahuan siswa, yaitu mengajukan pertanyaan, memberikan motivasi belajar pada siswa agar tidak jenuh saat pembelajaran berlangsung. Selanjutnya guru mengajukan permasalahan (problem statement) dengan bertanya. Siswa diberi kesempatan untuk menjawab pertanyaan dengan membuat hypothesis. Setalah itu, guru membagi siswa ke dalam 5 kelompok untuk melakukan percobaan dan mengisi lembar kerja (kegiatan data collections). Selain itu, guru menyediakan beberapa pertanyaan untuk membangun critical thinking (4C) pada siswa dalam menemukan rumus (disini siswa dituntut untuk berpikir kritis dalam menemukan jawaban dari permasalahan yang diajukan guru). Guru menunjuk salah satu kelompok untuk mempresentasikan hasil percobaan dan meminta kelompok lain menanggapi apakah ada hasil yang berbeda. Kegiatan selanjutnya merupakan data processing yaitu siswa dibantu guru untuk menarik kesimpulan. Siswa diajak kembali melihat jawaban atas permasalahan rumus yang sedang dicari, siswa diberi kesempatan untuk menguji hipotesisnya dan menjawab ulang permasalahan berdasarkan konsep baru yang telah didapat melalui percobaan sebelumnya (verification). Guru membimbing siswa untuk menemukan rumus dan menarik kesimpulan secara umum (generalization).

\section{c. Observasi dan Refleksi}

Pada pertemuan pertama siklus 1 kegiatan siswa dalam pembelajaran menggunakan model pembelajaran Discovery Learning berbasis Kurikulum 2013 diamati oleh observer. Pengamatan yang dilakukan dengan lembar observasi kegiatan guru dan siswa dalam proses belajar mengajar. Adapun pengamatan yang difokuskan pada kegiatan siswa dalam menerapkan model pembelajaran Discovery 
Learning berbasis Kurikulum 2013 dalam pembelajaran matematika karena sejalan dengan "aktivitas belajar siswa merupakan hal cukup penting dalam suatu proses pembelajaran" (Istiana, dkk, 2015). Hasil aktivitas siswa dalam pelajaran matematika selengkapnya dapat dilihat pada Tabel 2 di bawah ini:

\section{TABEL 2}

HASIL OBSERVASI AKTIVITAS SISWA SIKLUS 1

\begin{tabular}{|c|c|c|c|}
\hline Pertemuan & Materi & $\begin{array}{c}\text { Nilai } \\
\text { aktivitas }\end{array}$ & Kriteria \\
\hline $\begin{array}{c}\text { Siklus 1 } \\
\text { Pertemuan } \\
1\end{array}$ & $\begin{array}{c}\text { Luas dan } \\
\text { keliling }\end{array}$ & $69,56 \%$ & $\begin{array}{c}\text { Cukup } \\
\text { Baik }\end{array}$ \\
\cline { 1 - 1 } $\begin{array}{c}\text { Siklus 1 } \\
\text { Pertemuan } \\
2\end{array}$ & persegi & $78,26 \%$ & Baik \\
\hline
\end{tabular}

Pada pertemuan pertama siklus 1 aktivitas siswa dengan model pembelajaran Discovery Learning berbasis Kurikulum 2013 secara umum dapat dikatakan dilaksanakan sudah cukup baik. Kegiatan yang belum dilakukan yaitu menanggapi yang telah presentasi, mengamati rumus luas persegi, mencari rumus sisi persegi, melihat kembali jawaban atas permaslahan, dan melakukan refleksi kegiatan. Selama pembelajaran masih ditemui siswa ramai dan sebagian siswa bingung karena kurang mengerti tentang pembelajaran yang dilakukan, tetapi siswa tidak takut bertanya dengan guru, kebanyakan siswa sudah aktif dalam kegiatan pembelajaran berlangsung.

Pada pertemuan kedua siklus 1 aktivitas siswa dalam penerapan model pembelajaran Discovery Learning berbasis Kurikulum 2013 setelah diamati observer aspek yang belum dilakukan pada pertemuan pertama berkurang. Aspek yang belum dilakukan yaitu melakukan reflesi kegiatan. Walaupun masih ada siswa yang masih ramai tetapi sebagian besar siswa sudah mengerti alur pembelajaran yang dilakukan. Dilihat dari hasil tersebut bahwa aktivitas siswa menggunakan model pembelajaran Discovery Learning berbasis Kurikulum 2013 pada siklus 1 pertemuan pertama dan pertemuan kedua meningkat dari 69,56\% menjadi $78,26 \%$.

Pada pertemuan pertama siklus 1 penerapan model pembelajaran Discovery Learning berbasis Kurikulum 2013 secara umum dapat dikatakan dilaksanakan dengan cukup baik. Kegitan yang belum dilakukan yaitu menyebutkan tujuan pembelajaran. Selain itu, guru belum mengajak siswa melihat kembali jawaban atas permasalahan dan melakukan refleksi kegiatan pembelajaran.

Hasil aktivitas guru dalam pelajaran matematika selengkapnya dapat dilihat pada Tabel 3 di bawah ini:
TABEL 3

HASIL OBSERVASI AKTIVITAS GURU SIKLUS 1

\begin{tabular}{|c|c|c|c|}
\hline Pertemuan & Materi & Nilai aktivitas & Kriteria \\
\hline $\begin{array}{c}\text { Siklus 1 } \\
\text { Pertemuan 1 }\end{array}$ & $\begin{array}{c}\text { Luas } \\
\text { dan } \\
\text { keliling } \\
\text { persegi }\end{array}$ & $70,00 \%$ & $\begin{array}{c}\text { Cukup } \\
\text { Baik }\end{array}$ \\
\cline { 1 - 1 } $\begin{array}{c}\text { Siklus 1 } \\
\text { Pertemuan 2 }\end{array}$ & 80,00\% & Baik \\
\hline
\end{tabular}

Pada pertemuan kedua siklus 1 kegiatan guru dalam pembelajaran Discovery Learning berbasis Kurikulum 2013 setelah diamati oleh observer dapat dikatakan pembelajaran yang dilakukan guru baik. Pada pertemuan kedua ini aspek yang belum dilakukan pada pertemuan pertama berkurang. Kegiatan yang belum terpenuhi yaitu melakukan presensi dan melakukan refleksi kegiatan pembelajaran. Dilihat dari hasil di atas, aktivitas guru meningkat dari presentase 70,00\% menjadi 80,00\%.

Selain hasil aktivitas siswa dan guru, siklus 1 mendapatkan hasil belajar dari siswa selama 3 kali pertemuan. Hasil belajar didapat dari evaluasi siklus 1 yang dilaksanakan pada pertemuan 3 . Berikut ini merupakan tabel ketuntasan hasil belajar matematika siswa kelas 4 siklus 1 .

\section{TABEL 4}

KETUNTASAN HASIL BELAJAR MATEMATIKA SISWA KELAS 4 SIKLUS 1

\begin{tabular}{|c|c|c|c|c|}
\hline \multirow[b]{2}{*}{ No. } & \multirow[b]{2}{*}{ Nilai } & \multirow{2}{*}{$\begin{array}{c}\text { Ketuntasan } \\
\text { Belajar }\end{array}$} & \multicolumn{2}{|c|}{ Jumlah siswa } \\
\hline & & & Jumlah & $\begin{array}{l}\text { Prosen- } \\
\text { tase (\%) }\end{array}$ \\
\hline 1. & 67 & Tuntas & 15 & 75 \\
\hline 2. & $<67$ & Belum tuntas & 5 & 25 \\
\hline \multicolumn{3}{|c|}{ Jumlah } & 20 & 100 \\
\hline \multicolumn{3}{|c|}{ Rata - rata } & 75,50 & \\
\hline \multicolumn{3}{|c|}{ Nilai Tertinggi } & 100 & \\
\hline \multicolumn{3}{|c|}{ Nilai Terendah } & 40 & \\
\hline
\end{tabular}

Dari tabel 2 di atas, ketuntasan belajar siswa siklus 1 mengalami peningkatan yaitu 15 siswa dengan prosentase $75 \%$. Hal ini sejalan dengan hasil penelitian Yupita (2013: 10) menunjukkan bahwa pembelajaran dengan menggunakan model discovery dapat meningkatkan hasil belajar. Meskipun terjadi peningkatan ketuntasan belajar siswa setelah diberikan tindakan pada siklus I, diketahui bahwa ketuntasan belajar ini belum memberikan hasil yang diharapkan yaitu minimal $80 \%$ dari total siswa tuntas belajar atau tuntas KKM yang ditetapkan sekolah. Perlu adanya sorotan bagi 5 siswa yang belum tuntas. Artinya bahwa guru dalam menerapkan model pembelajaran Discovery Learning berbasis Kurikulum 2013 belum maksimal. Guru harus mengoptimalkan langkah-langkah pembelajaran 
yang belum seluruhnya dilaksanakan untuk mengoptimalkan pula aktivitas siswa yang akan berdampak pada hasil belajarnya. Dengan kata lain, dengan hasil ini diperlukan lagi tindakan yang harus dilaksanakan pada siklus 2 dengan persiapan yang lebih baik.

\section{Hasil Penelitian Siklus 2}

\section{a. Perencanaan}

Rencana tindakan pada siklus II hampir sama dengan siklus I. Akan tetapi pelaksanaan tindakan siklus II dilakukan dengan memperhatikan hasil refleksi pada siklus I. Perlengkapan yang dipersiapkan sebelum mengajar yaitu RPP, lembar observasi aktivitas guru, lembar observasi aktivitas siswa, intrumen penilian RPP, lembar kerja, soal evaluasi, dan media yang akan diguanakan. Langkah-langkah pada siklus II sama dengan langkah-langkah pada siklus I.

\section{b. Pelaksanaan}

Langkah-langkah pelaksanaan pembelajaran pada siklus I yang diterapkan oleh peneliti dimulai dengan guru melakukan stimulations pada apersepsi untuk membangun rasa keingintahuan siswa, yaitu mengajukan pertanyaan, memberikan motivasi belajar pada siswa agar tidak jenuh saat pembelajaran berlangsung. Selanjutnya guru mengajukan permasalahan (problem statement) dengan bertanya. Siswa diberi kesempatan untuk menjawab pertanyaan dengan membuat hypothesis. Setalah itu, guru membagi siswa ke dalam 5 kelompok untuk melakukan percobaan dan mengisi lembar kerja (kegiatan data collections). Selain itu, guru menyediakan beberapa pertanyaan untuk membangun critical thinking (4C) pada siswa dalam menemukan rumus (disini siswa dituntut untuk berpikir kritis dalam menemukan jawaban dari permasalahan yang diajukan guru). Guru menunjuk salah satu kelompok untuk mempresentasikan hasil percobaan dan meminta kelompok lain menanggapi apakah ada hasil yang berbeda. Kegiatan selanjutnya merupakan data processing yaitu siswa dibantu guru untuk menarik kesimpulan. Siswa diajak kembali melihat jawaban atas permasalahan rumus yang sedang dicari, siswa diberi kesempatan untuk menguji hipotesisnya dan menjawab ulang permasalahan berdasarkan konsep baru yang telah didapat melalui percobaan sebelumnya (verification). Guru membimbing siswa untuk menemukan rumus dan menarik kesimpulan secara umum (generalization).

\section{c. Observasi dan Refleksi}

Pada pertemuan pertama siklus 2 kegiatan siswa dalam pembelajaran menggunakan model pembelajaran Discovery Learning berbasis Kurikulum 2013 diamati oleh observer. Pengamatan yang dilakukan dengan lembar observasi kegiatan guru dan siswa dalam proses belajar mengajar. Adapun pengamatan yang difokuskan pada kegiatan siswa dalam menerapkan model pembelajaran Discovery Learning berbasis Kurikulum 2013 dalam pembelajaran matematika karena sejalan dengan "aktivitas belajar siswa merupakan hal cukup penting dalam suatu proses pembelajaran" (Istiana, dkk, 2015). Hasil aktivitas siswa dalam pelajaran matematika selengkapnya dapat dilihat pada Tabel 5 di bawah ini.

\section{TABEL 5}

HASIL OBSERVASI AKTIVITAS SISWA SIKLUS 2

\begin{tabular}{|c|c|c|c|}
\hline Pertemuan & Materi & Nilai aktivitas & Kriteria \\
\hline $\begin{array}{c}\text { Siklus 2 } \\
\text { Pertemuan 1 }\end{array}$ & \begin{tabular}{c} 
Luas dan \\
keliling \\
persegi \\
\cline { 3 - 4 }
\end{tabular} & $86,95 \%$ & Baik \\
$\begin{array}{c}\text { Siklus 2 } \\
\text { panjang }\end{array}$ & $95,65 \%$ & $\begin{array}{c}\text { Baik } \\
\text { Sekali }\end{array}$ \\
\hline
\end{tabular}

Pada pertemuan pertama siklus 2 aktivitas siswa dengan model pembelajaran Discovery Learning berbasis Kurikulum 2013 secara umum dapat dikatakan dilaksanakan sudah baik. Kegiatan yang belum dilakukan sudah berkurang dibandingkan dengan pelaksanaan siklus 1 . Selama pembelajaran masih ditemui sedikit yang siswa ramai. Namun, kebanyakan siswa sudah aktif dalam kegiatan pembelajaran berlangsung seperti tidak malu bertanya, aktif menanggapi yang telah presentasi, menjawab jika ditanya oleh guru.

Pada pertemuan kedua siklus 2 aktivitas siswa dalam penerapan model pembelajaran Discovery Learning berbasis Kurikulum 2013 setelah diamati observer aspek yang belum dilakukan pada pertemuan pertama berkurang. Kegitatan sepenuhnya dilakukan dengan baik sekali. Sebagian besar aspek kegiatan sudah terlaksana. Siswa semakin mengerti dengan alur pembelajaran menggukana model pembelajaran Discovery Learning berbasis Kurikulum 2013. Dilihat dari hasil tersebut bahwa aktivitas siswa menggunakan model pembelajaran Discovery Learning berbasis Kurikulum 2013 pada siklus 2 pertemuan pertama dan pertemuan kedua meningkat dari 86,95\% menjadi 95,65\%. Sejalan dengan hasil penelitian Rudyanto (2016: 47) bahwa penerapan model pembelajaran Discovery Learning dapat meningkatkan aktivitas siswa. Berdasarkan hasil penelitian yang dilaksanakan 
dalam siklus 2, dapat dikatakan bahwa aktivitas siswa sudah dilaksanakan semuanya dengan baik.

Hasil aktivitas guru dalam pelajaran matematika selengkapnya dapat dilihat pada Tabel 6 di bawah ini:

TABEL 6

\section{HASIL OBSERVASI AKTIVITAS GURU SIKLUS 2}

\begin{tabular}{|c|c|c|c|}
\hline Pertemuan & Materi & Nilai aktivitas & Kriteria \\
\hline $\begin{array}{c}\text { Siklus 2 } \\
\text { Pertemuan 1 }\end{array}$ & $\begin{array}{c}\text { Luas } \\
\text { dan } \\
\text { keliling } \\
\text { persegi } \\
\text { panjang }\end{array}$ & $85,00 \%$ & Baik \\
\cline { 1 - 1 } $\begin{array}{c}\text { Siklus 2 } \\
\text { Pertemuan 2 }\end{array}$ & 95,00\% & $\begin{array}{c}\text { Baik } \\
\text { Sekali }\end{array}$ \\
\hline
\end{tabular}

Pada pertemuan pertama siklus 2 penerapan model pembelajaran Discovery Learning berbasis Kurikulum 2013 secara umum dapat dikatakan dilaksanakan dengan baik. Guru sudah melaksanakan kegiatan pembelajaran dengan teliti. Walaupun belum sepenuhnya terlaksana semua.

Pada pertemuan kedua siklus 2 kegiatan guru dalam pembelajaran Discovery Learning berbasis Kurikulum 2013 setelah diamati oleh observer dapat dikatakan pembelajaran yang dilakukan guru baik sekali. Pada pertemuan kedua ini aspek yang belum dilakukan pada pertemuan pertama berkurang. Sebagian besar aspeknya telah dilaksanakan. Dilihat dari hasil di atas, aktivitas guru meningkat dari presentase $85,00 \%$ menjadi 95,00\%. Dapat disimpulkan kegiatan pembelajaran menggunakan model Discovery Learning berbasis Kurikulum 2013 pada mata pelajaran matematika siswa kelas 4 SDN 11 Kutowinangun 11 Salatiga dari setiap pertemuan mengalami peningkatan yang ditunjukkan dari nilai persentase kegiatan guru mengajar. Jika dilihat dari seluruh kegiatan pembelajaran yang direncanakan, maka dapat dikatakan kegiatan pembelajaran siklus 2 berhasil.

Siklus 2 mendapatkan hasil belajar dari siswa selama 3 kali pertemuan. Hasil belajar didapat dari evaluasi siklus 2 yang dilaksanakan pada pertemuan 3. Berikut ini merupakan tabel ketuntasan hasil belajar matematika siswa kelas 4 siklus 2.

TABEL 7

KETUNTASAN HASIL BELAJAR MATEMATIKA SISWA KELAS 4 SIKLUS 1

\begin{tabular}{|l|c|l|c|c|}
\hline \multirow{2}{*}{ No. } & \multirow{2}{*}{ Nilai } & \multirow{2}{*}{$\begin{array}{c}\text { Ketuntasan } \\
\text { Belajar }\end{array}$} & \multicolumn{2}{|c|}{ Jumlah siswa } \\
\cline { 4 - 5 } & & & $\begin{array}{c}\text { Presen- } \\
\text { tase (\%) }\end{array}$ \\
\hline 1. & 67 & Tuntas & 18 & 90 \\
\hline 2. & $<67$ & Belum tuntas & 2 & 10 \\
\hline
\end{tabular}

\begin{tabular}{|c|c|c|}
\hline Jumlah & 20 & 100 \\
\hline Rata - rata & $\mathbf{8 3 , 0 0}$ & \\
\hline Nilai Tertinggi & $\mathbf{1 0 0}$ & \\
\hline Nilai Terendah & $\mathbf{5 0}$ & \\
\hline
\end{tabular}

Dari tabel 7 di atas, ketuntasan belajar siswa siklus 2 mempunyai jumlah yang banyak yaitu 18 siswa dengan prosentase 90\%. Dapat dilihat juga antara nilai terendah dan nilai tertinggi memiliki kesenjangan yang tidak begitu jauh dibandingkan pada pra siklus. Selain itu, perlu adanya sorotan bagi 2 siswa yang belum tuntas. Artinya bahwa penerapan model pembelajaran Discovery Learning berbasis Kurikulum 2013 dapat meningkatkan ketuntasan belajar siswa dengan dibuktikannya data di atas. Seirama dengan hasil penelitian Fitrianingtyas dan Radia (2017: 719) serta Supriyadi (2013: 13) bahwa penerapan model pembelajaran Discovery Learning dapat meningkatkan hasil belajar. Walaupun masih ada siswa yang belum memenuhi KKM yang ditetapkan, karena berbagai faktor dari dalam maupun dari luar siswa itu sendiri (Slameto, 2003: 60). Hasil belajar yang diperoleh pada siklus 2 ini mengalami peningkatan dari siklus 1 .

\section{Perbandingan Antar Siklus}

Berikut terdapat tabel hasil belajar siswa sebelum diberi tindakan (pra siklus), siklus 1 dan siklus 2 serta hasil rekapitulasi perbandingan hasil belajar dalam tabel 8 dibawah ini.

\section{TABEL 8}

\section{PERBANDINGAN KETUNTASAN HASIL BELAJAR} MATEMATIKA PRA SIKLUS, SIKLUS 1 DAN SIKLUS 2 SISWA KELAS 4

\begin{tabular}{|c|c|c|c|c|c|c|c|}
\hline \multirow{2}{*}{ No } & $\begin{array}{c}\text { Ketun- } \\
\text { tasan } \\
\text { Hasil } \\
\text { Belajar }\end{array}$ & \multicolumn{2}{|c|}{$\begin{array}{c}\text { Pra } \\
\text { Siklus }\end{array}$} & \multicolumn{2}{|c|}{ Siklus 1 } & \multicolumn{2}{c|}{ Siklus 2 } \\
\cline { 3 - 8 } & (f) & (\%) & (f) & (\%) & (f) & (\%) \\
\hline 1. & Tuntas & 10 & $\begin{array}{c}50 \\
\%\end{array}$ & 15 & $75 \%$ & 18 & $\begin{array}{c}90 \\
\%\end{array}$ \\
\hline 2. & $\begin{array}{c}\text { Tidak } \\
\text { Tuntas }\end{array}$ & 10 & $\begin{array}{c}50 \\
\%\end{array}$ & 5 & $25 \%$ & 2 & $10 \%$ \\
\hline \multicolumn{2}{|c|}{ Jumlah } & 20 & $\begin{array}{c}100 \\
\%\end{array}$ & 20 & $\begin{array}{c}100 \\
\%\end{array}$ & 20 & $\begin{array}{c}100 \\
\%\end{array}$ \\
\hline Nilai Rata-rata & \multicolumn{2}{|c|}{62,25} & \multicolumn{2}{|c|}{75,50} & 83,00 \\
\hline Nilai Terendah & \multicolumn{2}{|c|}{20} & \multicolumn{2}{|c|}{40} & \multicolumn{2}{|c|}{50} \\
\hline \multicolumn{2}{|c|}{ Nilai Tertinggi } & \multicolumn{2}{|c|}{90} & \multicolumn{2}{|c|}{100} & \multicolumn{2}{|c|}{100} \\
\hline
\end{tabular}

Berdasarkan perbandingan hasil belajar yang berkaitan dengan nilai prosentase dan jumlah siswa dalam tabel 8 dapat diketahui bahwa nilai rata-rata hasil belajar matematika SDN Kutowinangun 11 meningkat. Dibuktikan dari nilai rata-rata pra siklus sebesar 62,25 pada siklus 1 meningkat menjadi 75,50 dan kemudian pada siklus 2 terjadi peningkatan lagi 
menjadi 83,00. Selain dari sisi nilai rata-rata, nilai minimal dan nilai maksimal siswa juga mengalami peningkatan. Skor minimal pada pra siklus sebesar 20, meningkat pada siklus I sebesar 40, dan kembali meningkat menjadi 50. Skor maksimal pada pra siklus 90, meningkat pada siklus 1 dan 2 menjadi 100.

Jumlah siswa yang tuntas dari KKM yang telah ditentukan yaitu $\geq 67$ semakin meningkat. Pada pra siklus yang didapatkan dari nilai ulangan terdapat 10 siswa atau 50\% dari keseluruhan jumlah siswa yang telah mencapai KKM yang ditentukan yaitu $\geq 67$. Sebanyak 10 siswa atau 50\% dari keseluruhan jumlah siswa masih memperoleh nilai dibawah KKM. Pada siklus 1 setelah diberi tindakan dengan menerapkan model pembelajaran Discovery Learning berbasis Kurikulum 2013 jumlah siswa yang tuntas meningkat menjadi 15 siswa atau $75 \%$ dari keseluruhan jumlah siswa yang belum tuntas dan akan diberikan perbaikan pembelajaran di siklus 2. Pada siklus 2 setelah diperbaiki kembali proses pembelajaran dengan menggunakan model pembelajaran Discovery Learning berbasis Kurikulum 2013 jumlah siswa yang tuntas meningkat kembali menjadi 18 siswa atau 90\% dari keseluruhan jumlah siswa. Sepaham dengan pernyataan peningkatan hasil belajar tentunya didahului dengan perbaikan kualitas proses pembelajaran yang dilakukan guru dengan memperhatikan hasil evaluasi dan refleksi di tiap-tiap pertemuan dan tiap siklus (Rismayani, 2013: 10).

Namun masih ada 2 siswa yang belum mencapai nilai $\mathrm{KKM} \geq 67$. Untuk siswa yang belum tuntas dicarai tahu sebabnya melalui wawancara sederhana dengan guru kelas dan kepala sekolah tentang latar belakang siswa tersebut. Setelah penulis melakukan tanya jawab dengan guru kelas dan kepala sekolah dapat diketahui bahwa siswa yang belum mencapai ketuntasan tersebut memiliki latar belakang yang berbeda-beda. Salah satu faktor yang menghambat siswa untuk mencapai nilai ketuntasan minimum adalah rendahnya tingkat pemahaman siswa dalam menerima materi dan latar belakang orang tua yang kurang memperhatikan siswa. Siswa yang belum mencapai ketuntasan minimal tidak hanya disebabkan dari sekolah dan dari orang tua yang kurang memperhatikan siswa, tetapi karena faktor internal yang lain. Sejalan dengan pendapat Slameto (2003: 54) faktor yang mempengaruhi hasil belajar berasal dari faktor internal dan faktor eksternal.

\section{TEMUAN ATAU DISKUSI}

Penelitian tindakan ini adalah peningkatan hasil belajar matematika siswa kelas 4 SDN Kutowinangun 11 Salatiga melalui model pembelajaran Discovery Learning berbasis Kurikulum 2013. Pemberian tindakan dalam penelitian ini berlangsung selama 2 siklus setiap siklus terdiri dari 3 kali pertemuan. Pada siklus 1 pertemuan pertama dengan materi mencari rumus luas bangun persegi menggunakan benda konkrit. Dari pengamatan terhadap proses pembelajaran yang dilakukan didapatkan permasalahan antara lain siswa kurang mengerti tentang model pembelajaran Discovery Learning berbasis Kurikulum 2013, dalam proses pembelajaran masih banyak siswa sibuk sendiri dan membuat keramaian kelas. Selain itu karena terbiasa dengan proses pembelajaran yang lalu dengan menggunakan model pembelajaran konvensional yaitu guru menjadi sumber utama dalam pembelajaran. Pada pertemuan kedua siklus 1 masih ditemukan permasalahan seperti pertemuan pertama, sehingga guru terus menerus untuk memotivasi siswa untuk mau berperan aktif dalam mengikuti pembelajaran. Walaupun kegiatan-kegiatan yang direncanakan sudah banyak dilakukan tetapi kurang optimal yang ditujukan hasil penilaian observer terhadap pembelajaran yang dilakukan masih di bawah kriteria baik sekali.

Pada pertemuan siklus 2 masalah-masalah tersebut sudah berkurang, yang ditunjukkan antara lain: siswa sudah terbiasa menempatkan diri sesuai tanggung jawab kelompok masing-masing berdasarkan perintah guru sehingga kondisi kelas tidak ramai dan siswa mulai terbiasa dengan model pembelajaran Discovery Learning berbasis Kurikulum 2013. Aktivitas siswa meningkat karena pembelajaran tersebut menuntut siswa untuk berpikir kritis (4C) dan melakukan kegiatan-kegiatan yang bersifat menemukan pengetahuannya sendiri. Serupa dengan pernyataan Discovery learning adalah metode yang mendorong siswa untuk sampai pada suatu kesimpulan berdasarkan pada aktivitas siswa itu sendiri dan observasinya oleh Balım (2009: 2).

Pelaksanaan pembelajaran dengan menerapkan model pembelajaran Discovery Learning berbasis Kurikulum 2013 tidak hanya dapat meningkatkan hasil belajar saja. Tetapi juga dapat meningkatkan aktivitas dan berpikir kritis (4C) siswa sehingga mempengaruhi hasil belajar. Hal tersebut sejalan dengan pernyataan bahwa tahapan-tahapan dari model Discovery Learning dapat mengembangkan sikap ilmiah, rasa ingin tahu, pemahaman konsep, dan sikap kritis siswa yang berpengaruh pada meningkatkan hasil belajar (Widiadnyana, 2014: 8).

Ada kenaikan hasil belajar dari pra siklus sampai siklus 2. Sejalan dengan penelitian Supriyanto (2014: 173) dan Hasugian, dkk (2013: 13) bahwa hasil belajar matematika pada siswa mengalami peningkatan dengan penerapan Discovery Learning. Nilai siswa yang diatas KKM dari pra siklus 10 siswa meningkat pada siklus 1 menjadi 15 siswa, meningkat lagi pada siklus 2 menjadi 18 siswa dari 20 siswa. Nilai rata-rata dan ketuntasan hasil belajar siswa sebelum tindakan kelas dilaksanakan juga mengalami peningkatan dari nilai rata-rata 62,25 dengan ketuntasan klasikal 50\% siswa tuntas dan setelah dilaksanakan tindakan dengan menggunakan model pembelajaran Discovery Learning berbasis Kurikulum 2013 pembelajaran nilai rata-rata siklus 1 
menjadi 75,50 dengan ketuntasan belajar mencapai $75 \%$ siswa tuntas, sedangkan pada siklus 2 nilai rata-rata siswa meningkat menjadi 83,00 dengan ketuntasan klasikal mencapai 90\% siswa tuntas hasil belajarnya.

Temuan yang didapat dari penelitian ini yaitu adanya perbedaan dengan penelitian sebelumnya. Pertama, langkah-langkah model pembelajaran Discovery Learning pada penelitian terdahulu belum disesuaikan dengan pendekatan saintifik kurikulum 2013. Sedangkan penelitian ini merupakan penerapan model pembelajaran Discovery Learning berbasis kurikulum 2013. Langkah-langkahnya telah disesuaikan dengan kurikulum 2013 yaitu memuat 5m (menanya, mengamati, menalar, mencoba, dan mengkomunikasikan). Oleh karena itu, penggunaan model pembelajaran Discovery Learning berbasis kurikulum 2013 dapat meningkatkan hasil belajar siswa. Kedua, pada penelitian sebelumnya belum ada $4 \mathrm{c}$ dalam pembelajarannya. Pada tahap data collections atau pengumpulan data dalam langkah-langkah pembelajaran Discovery Learning berbasis kurikulum 2013, disediakan beberapa pertanyaan untuk menuntun siswa berpikir kritis (critical thinking). Sehingga yang terjadi adalah siswa lebih bisa menemukan dan membangun pengetahuannya dengan diterapkannya model ini. Ketiga, kegiatan evaluasi dilakukan pada penelitian terdahulu belum menggunakan soal-soal yang memuat HOTS. Sedangkan penelitian ini, soal-soal evaluasi menggunakan soal HOTS. Disesuaikannya soalsoal HOTS tersebut membuat siswa mengembangkan ketrampilan berpikir tingkat tinggi.

\section{E. SIMPULAN DAN SARAN}

Berdasarkan hasil penelitian dan pembahasan, sebagai mana diuraikan di atas dapat disimpulkan bahwa model pembelajaran Discovery Learning Berbasis Kurikulum 3013 dapat meningkatkan aktivitas siswa dalam berpikir kritis (critical thinking) dalam $4 \mathrm{C}$ sehingga berpengaruh pada hasil belajar matematika kelas 4 di salah satu SD Negeri kota Salatiga. Hal ini ditunjukan oleh angka ketuntasan pra siklus, siklus 1 dan siklus 2. Pada pra siklus sebelum diberikannya tindakan ketuntasan hasil belajar siswa dalam kelas hanya 50\% yang tuntas atau 10 siswa dengan rata-rata 62,25. Setelah diberikannya tindakan dengan menggunakan model pembelajaran Discovery Learning Berbasis Kurikulum 3013 pada siklus 1 ketuntasan hasil belajar siswa meningkat menjadi $75 \%$ atau 15 siswa dengan rata-rata 75,50, pada siklus 2 ketuntasan hasil belajar siswa meningkat mencapai $90 \%$ atau 18 siswa dengan rata-rata 83,00.

Berdasarkan kesimpulan diatas maka peneliti mengajukan beberapa saran untuk dijadikan masukan yang berguna, diantaranya adalah guru diharapkan dapat menggunakan model pembelajaran Discovery Learning Berbasis Kurikulum 3013 untuk menciptakan suasana belajar yang berbeda dan membuat siswa menjadi aktif dalam mengikuti pembelajaran, guru dapat menggunakan model ini untuk meningkatkan kualitas guru dalam mengajar sehingga siswa menjadi lebih kritis dalam mengikuti pembelajaran. Penerapkan Discovery Learning Berbasis Kurikulum 3013, diharapkan dapat menyelesaikan permasalahan yang muncul dalam kehidupan sehari-hari dengan cara belajar matematika yang menarik.

\section{UCAPAN TERIMA KASIH}

Penulis mengucapkan terimakasih kepada semua pihak SD Negeri kota Salatiga yang telah mengijinkan dilaksanakannya penelitian ini. Sehingga penelitian ini dapat selesai dengan baik.

\section{DAFTAR RUJUKAN}

[1] Astuti, M. S. (2015). Peningkatan Keterampilan Bertanya dan Hasil Belajar Siswa Kelas 2 SDN Slungkep O3 Menggunakan Model Discovery Learning. Scholaria: Jurnal Pendidikan dan Kebudayaan, 5(1), 10-23.

[2] Balım, A. G. (2009). The Effects of Discovery Learning on Students' Success and Inquiry Learning Skills. Eurasian Journal of Educational Research (EJER), (35), 1-20.

[3] Ebbutt, S. 1995. Mathematics in Primary Schools: Children and Mathematics. United Kingdom: Collins Educational.

[4] Fitrianingtyas, A., \& Radia, E. H. (2017). Peningkatan Hasil Belajar IPA Melalui Model Discovery Learning Siswa Kelas IV SDN Gedanganak 02. Jurnal Mitra Pendidikan, 1(6), 708-720.

[5] Hapsari, Agni Era. (2017). Penerapan Model Pembalajaran Kooperatif Tipe NHT Berbantuan Media Interaktif untuk Meningkatkan Aktivitas dan Prestasi Belajar Siswa. Scholaria: Jurnal Pendidikan dan Kebudayaan, 7(1), 1-9.

[6] Hasugian, H., Tampubolon, B., \& Margiati, K. Y. (2013). Meningkatkan Hasil Belajar Siswa dalam Pembelajaran Matematika dengan Metode Discovery Learning pada Anak Kelas VI Sekolah Dasar Negeri o2 Sejaruk Param. Jurnal Pendidikan dan Pembelajaran, 2(9).

[7] Illahi, Mohammad Takdir. 2012. Pembelajaran Dicovery Strategy dan Mental Vocational Skill. Jogjakarta: Diva Press.

[8] Istiana, G. A., Saputro, A. N. C., \& Sukardjo, J. S. (2015) Penerapan Model Pembelajaran Discovery Learning untuk Meningkatkan Aktivitas dan Prestasi Belajar Pokok Bahasan Larutan Penyangga pada Siswa Kelas XI IPA Semester II SMA Negeri 1 Ngemplak Tahun Pelajaran 2013/2014. Jurnal Pendidikan Kimia, 4(2), 65-73.

[9] Pakpahan, R. (2014). Upaya Meningkatkan Hasil Belajar Siswa Dengan Menggunakan Metode Discovery Pada Mata Pelajaran Matematika Di Kelas Iv Sd Negeri 155686 Untemungkur Ii Kecamatan Kolang Kabupaten Tapanuli Tengah. School Education Journal PGSD FIP Unimed, 1(2).

[10] Pratiwi, F. A., \& Rasmawan, R. (2014). Pengaruh Penggunaan Model Discovery Learning Dengan Pendekatan Saintifik Terhadap Keterampilan Berpikir Kritis Siswa SMA. Jurnal Pendidikan dan Pembelajaran, 3(7), $1-16$

[11] Riedesel, C.A., et al. 1996. Teaching Elementary School Mathematics. MA: A Simon and Schuster Company.

[12] Rismayani, N. L. (2013). Penerapan Model Pembelajaran Discovery Learning untuk Meningkatkan Hasil Belajar PKn Siswa. Jurnal Pendidikan Kewarganegaraan Undiksha, 1(2). 
[13] Rudyanto, H. E. (2016). Model Discovery Learning dengan Pendekatan Saintifik Bermuatan Karakter untuk Meningkatkan Kemampuan Berpikir Kreatif. Premiere Educandum: Jurnal Pendidikan Dasar dan Pembelajaran, 4(O1).

[14] Slameto. 2003. Belajar dan Faktor-Faktor yang Mempengaruhinya. Jakarta: Rineka Cipta.

[15] Sudjana. 2004. Penilaian Hasil Proses Belajar Mengajar. Bandung: Remaja Rosdakarya.

[16] Supriyadi, Agus. (2013). Peningkatan Hasil Belajar Metode Discovery Pembelajaran IPA Kelas IV SDN O3 Sungai Ambawang Kubu Raya. Jurnal PGSD FKIP Universitas Tanjungpura Pontianak. 5 (1), 2-14.

[17] Supriyanto, B. (2014). Penerapan Discovery Learning untuk Meningkatkan Hasil Belajar Siswa Kelas VI B Mata Pelajaran Matematika Pokok Bahasan Keliling Dan Luas Lingkaran di SDN Tanggul Wetan 02 Kecamatan Tanggul Kabupaten Jember. Pancaran Pendidikan, 3(2), 165-174.

[18] Van Joolingen, W. (1998). Cognitive tools for discovery learning. International Journal of Artificial Intelligence in Education (IJAIED), 10, 385-397.

[19] Widiadnyana, I. W., Sadia, I. W., \& Suastra, I. W. (2014). Pengaruh Model Discovery Learning Terhadap Pemahaman Konsep IPA dan Sikap Ilmiah Siswa SMP. Jurnal Pendidikan IPA Indonesia, 4(1).

[20]Yupita, I. A., \& Tjipto, W. (2013). Penerapan Model Pembelajaran Discovery untuk Meningkatkan Hasil Belajar IPS di Sekolah Dasar. Jurnal Penelitian Pendudukan Guru Sekolah Dasar, 1(O2), 207-216.

\section{PROFIL PENULIS UTAMA}

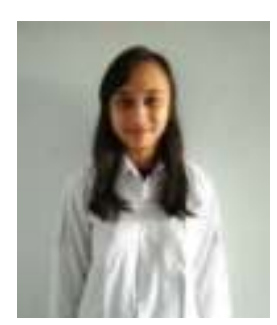

Penulis bernama lengkap "Rosemey
Ratna Purnawati". Lahir di desa
Wotbuwono Kecamatan Klirong

Kabupaten Kebumen Provinsi Jawa Tengah pada tanggal 5 Mei 1996 dari pasangan Rusmanto dan Rimbat Setyaningsih. Penulis adalah anak ketiga dari 3 bersaudara. Pendidikan sekolah dasar mulai dari SDN Wotbuwono Kecamatan Klirong pada tahun 2002- 2008. Setelah itu melanjutkan pendidikan sekolah menengah ke SMPN 5 Kebumen pada tahun 2008 2011 dan terakhir di SMAN 2 Kebumen pada tahun 2011 2014. Kemudian penulis melanjutkan studi ke perguruan tinggi di Program Studi Pendidikan Guru Sekolah Dasar FKIP Universitas Kristen Satya Wacana pada tahun 2014. Kritik, saran, maupun hal-hal yang berkaitan dengan kelanjutan atau pengembangan dari hasil penelitian ini bisa dikirim ke email penulis di: rosemeyosi@gmail.com. 